\title{
STRATEGY OF RESEARCH INSTITUTES IN CONSTRUCTION IN SHAPING THE RESEARCH AREA
}

\author{
MARCIN M. KRUK ${ }^{1}$
}

\begin{abstract}
The model concept, as presented in this paper, is an original solution created by the author, and can be used as a proposal to build an innovative mechanism to increase the effectiveness of programming and implementation of the development policy, and improve the quality of functioning of a building research institute. The development management system included in this model is a set of actions targeting at the effective use of human and tangible resources, undertaken in a coordinated manner and leading to the achievement of previously established objectives. The market activity of building research institutes is directly or indirectly involved in construction projects, which translates into market mechanisms, such as innovation and competitiveness. In addition, it indicates the participation of a building research institute in the engineering of construction projects as a key to entrepreneurship and implementations.
\end{abstract}

Keywords: research institute, innovation, competitiveness, development strategy, construction processes, engineering construction projects

\section{INTRODUCTION}

In an era of innovation, accounting records are saying less and less about the organisation's ability to compete in current market conditions. The role of knowledge and other intangible assets (e.g. organisational culture or customer loyalty) in the creation of the ability of the enterprise to compete and succeed is considered a key characteristic under these conditions. The primary value of research institutes is the knowledge and intellectual capital surrounding organisational culture that is conducive to being open to innovativeness and entrepreneurship in the cooperation between science and business.

\footnotetext{
${ }^{1}$ DSc., PhD., Eng., Building Research Institute, 1 Filtrowa St., 00-611 Warsaw, Poland. e-mail: m.kruk@itb.pl
} 
The creation of systemic growth in the scientific effectiveness of innovation and implementation for the purpose of using science to raise the civilisational level of the economy, is a challenge faced by the national economy. It is mainly growth based on innovation and further accumulation of technically advanced capital that makes it possible to significantly enhance productivity, and move from medium to high macroeconomic income. Research institutes are statutorily involved in the challenges associated with the increase in the competitiveness of the economy because [1] the core activity of an institute includes conducting scientific research and development; adapting the research and development results to the needs of the practice; and implementation of the research and development results.

In the scientific discipline of construction, science and engineering intermingle. As noted: the emerging large scale engineering works that impact the safety of hundreds of users and have the designed life of dozens of years must be accompanied by the conviction that they are scientifically based [2].

Research and development in the scientific discipline of construction (we will use the term construction below in this paper) should be considered within $\mathrm{E}^{3}$ (Energy $\times$ Environment $\times$ Economics), i.e. within the limits set by the minimum energy consumption, the minimum impact on the environment and economic rationalisation [3], and, as such, must comply with the requirements of sustainable development. [4] As construction is one of the oldest fields of technology, and uses many basic, technical and social scientific disciplines, research is conducted in many scientific institutions. Construction, as a scientific discipline, can effectively develop through the permanent connection between science and practice as part of large scale projects, where practice has often been well ahead of theory [5].

In Poland, research related to construction is conducted by three types of institutions: institutes of the Polish Academy of Sciences PAN, research institutes, and other specialised units and technical universities [6]. The main direction of the scientific activity of PAN units includes theoretical analyses and experimental research, whereas universities focus on education (which cannot be undertaken without a well-conducted internal research). Research institutes, particularly those associated with construction, focus mainly on those activities relating to the application, improvement or increasing the scale and scope of application of the known, in close connection with science and the practice. The primary activity of research institutes specified in the legislation is consistent with the words of Joseph Schumpeter, who noted that technological change in the production of commodities already in use, the opening up of new markets or of new sources of supply, Taylorisation of production, improved material handling, the setting up of new business 
organisations - in short, any "doing things differently" in the realm of economic life - are all instances of what we shall refer to by the term Innovation [7]. The analysis of data relating to the parametric evaluation of Polish scientific units for the period of 2009-2012 suggests that research institutes, which employ $13 \%$ of Polish researchers, are responsible for $34 \%$ of the scientific achievements and $84 \%$ of implementations from Polish science [8]. Therefore, when considering innovation and the competitive economy, it is advisable to analyse the management mechanisms used in research institutes that stimulate development and innovation. The ability and motivation to continue to explore and practically apply the results of research and development, new concepts, ideas and inventions as the foundation of a competitive economy, are assigned not only to entrepreneurs, but in particular to research institutes closely cooperating with entrepreneurs. Thus, the delineated market mechanism became a starting point for the proposal of a model for the development management system of a research institute as presented in this paper. The management model is aimed at increasing the effectiveness of programming and implementation of the development policy, and raising the quality of the functioning of the research institute in the context of the knowledge-based economy.

The strategic approach presented in this article, including the adopted actions, is part of the strategy for the European building research institutes affiliated with the European Network of Building Research Institutes (ENBRI) [9]. The building research institutes play a very important role in construction projects, at the stage of both innovation and implementation, and in the capacity of a building expert and surveyor operating directly within a construction project. A construction project $[10,11]$ encompasses activities such as conceptual preparation, organisation and completion of the construction, assembly, refurbishment and demolition, as well as the coordination and monitoring of management processes and various construction processes. At all these stages of the project the main elements are the issues of economics, finance and human resource management $[12,13]$ as well as the innovations associated with research institutions. Therefore, the knowledge and intellectual capital of the scientific unit play a special part in these activities. The building research institute is not only an institutional surveyor participating directly in construction projects, but also - or rather above all - a scientific unit that is indirectly involved in construction projects from programming and planning to demolition and recycling of materials by conducting research and development for the purposes of the practice. 


\section{INNOVATION AND COMPETITIVENESS}

\subsection{INNOVATION AS AN ENTREPRENEURIAL TOOL IN THE CONTEXT OF RESEARCH INSTITUTE MANAGEMENT}

Innovativeness is closely linked to the concept of innovation, and should be understood both as an act of a qualitative change in the economy once the production of a new product begins, and as the product (or process) itself [14]. However, the basic definition used by professionals studying technological change is the definition formulated by the already quoted J. Schumpeter, innovation introduces a new method of the means of production [15]. Innovation became a subject of interest to economic theorists, managers, business practitioners and consultants because it represents a specific entrepreneurial tool with which they can use a resulting change as an opportunity to implement a different business. From the viewpoint of strategic management, the most important is the division into technological and organisational innovations (Figure 1).

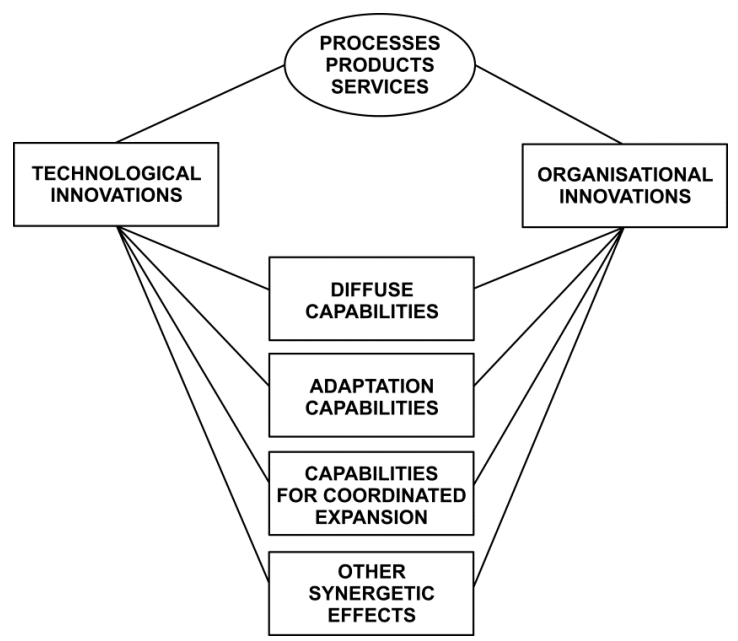

Fig. 1.The basic relationship between technological and organisational innovations [16]

In highly developed countries, a special role is assigned to the relationship between competitiveness and innovation. Economic innovation should be understood as the ability and incentive of economic operators to continue to search for and practically apply new results of research and development, new concepts and ideas. Innovation consists of the preparation and launch of production of new or 
improved materials, products, equipment, services, processes or methods for a market or another practical application [17]. Entrepreneurs should intentionally look for changes and indicators that highlight the possibility for the introduction of innovations. However, for a project to be called entrepreneurial, it should demonstrate some special characteristics. For example, launching a renovation business in the construction market by a small company is not synonymous with entrepreneurship, as this may be just generic behaviour (a copy of many other such activities). In fact, entrepreneurs form a minority among new companies, because an entrepreneur is mostly someone who creates something new, something different, changes or transforms values, regardless of whether the enterprise is small and new or large and old. An example of a large and old company is General Electric. More than one hundred years old, it is one of the largest companies in the world. In its long history, it has established many new entrepreneurial businesses from scratch and developed them into large industries. Often, a special innovation-oriented characteristic of the entrepreneur is the use of practical solutions that are ahead of theory, despite the fact that the practice is based on theory, even if the practitioners themselves are not aware of this. Entrepreneurship is based on the theory of economics and society.

In the context of entrepreneurship, one can be tempted to delineate a small difference in the activities that may mean the same thing in principle - namely, doing something else and doing something better, which is already being done. It is basically what the French economist JeanBaptiste Say meant when he coined the term entrepreneur two hundred years ago. The term was supposed to be a manifesto and statement of dissent because the entrepreneur causes anxiety and disorganisation. Joseph Schumpeter formulated this as follows: the task of the entrepreneur is to perform creative destruction [18].

This viewpoint goes back to the source of economics, and the work An Inquiry into the Nature and Causes of the Wealth of Nations, by the Scottish thinker and economist Adam Smith, first published in 1776. This work is considered the first scientific analysis of economic phenomena, and the date of its publication is conventionally treated as the date of the birth of modern economics. J. B. Say admired Adam Smith and promoted his concepts and strategies throughout his life. However, his own contribution to economic thought - the concept of the entrepreneur and entrepreneurship - is independent of classic economics and, in fact, even incompatible with it. Classic economics optimises what already exists, as does the mainstream of economic theory to the present day, including the proponents of Keynes, Friedmann and economic interventionism. In classic terms, entrepreneurship is based on extracting the maximum potential from existing resources in order to achieve a balance. 
Joseph Schumpeter was the first major economist to return to the concept first propagated by J. B. Say. He broke with the traditional economics and postulated that it is the dynamic imbalance introduced by the innovative entrepreneur, not balance and optimisation, that are the standard for a healthy economy and the most important reality of economic theory and practice [18].

Balance and optimisation - one may get the impression - is currently a permanent element of the management of scientific institutions. Entrepreneurs, or the first clients of scientific units, see change as something normal and healthy. It is through change that entrepreneurs introduce innovation, which is a specific development tool for them. They do not cause change themselves, but always look for, respond to and use it as an opportunity. Change is a constant element in their activity and does not have to be risky in the modern entrepreneurship methodology, but it should be consistent and structured. First of all, it should be based on a targeted innovation. In order to facilitate the transfer of knowledge from research institutions to enterprise, one needs to strengthen the entrepreneurial approach in science so that the communication on the science-business level can occur through the relationship with entrepreneurship, because it is the dynamic imbalance introduced by the innovative entrepreneur, not balance and optimisation, that is the standard for a healthy economy.

In many research institutes, one can observe a non-optimal use of research potential leading to implementation, which is the statutory obligation of these units. Between 2010 and 2013, a check was carried out in selected research institutes [19] from which it was determined that this activity largely involves the performance of highly specialised, albeit routine, work for public administration and economic operators: expert reports, feasibility studies, analyses of conditions, reports on compliance with standards, as well as the fulfilment of tasks of public services. The nonoptimal use of research potential in institutes may have been impacted by the lack of specification of the direction of development of their activity, the engagement in service activities, the insufficient development of young scientific personnel resulting in a generational gap, and the inadequate performance of periodic evaluations of employees.

A summary of the above can be the statement relating to the assessment of the activity of a research institute that it is striking that the need for change in its global functioning was observed in an institute that was perceived as well-run. This is an innovation in its own right, in the context of the activities of the institute, the management mechanisms related to decisions and standards, incentives, information flow, mind-set or the organisational structure. All these activities are closely linked to the model of the development management system for a research institute and oriented at the development of the potential related to the implementation activity. Entrepreneurs and scientific 
units should see change as something normal and healthy, but it must be managed by combining science and business.

\subsection{REACTIONS TO CHANGE VS. COMPETITIVENESS AND ENTREPRENEURSHIP}

The functioning of research institutes on the market in a situation of permanent change in economic conditions that take place as a result of the ICT revolution, the process of globalisation and regional integration, depends on the continued ability to maintain the existing or create new competitive advantage. The above is possible, first and foremost, via skilful change management, where, according to L. Clarke, the first step in change management is entrepreneurship [20] - oriented around the management of the competitiveness of enterprises. The adoption of innovation as a goal and a premise for the permanent restructuring of resources makes it possible to achieve, strengthen and defend one's leading position in the market. A focus on sustainable development involves the constant overcoming of weakness and, in the context of the organisation, transforming risks into opportunities. This is change management aimed at maintaining competitive advantage.

Plant and equipment as well as intangible assets owned or used by the enterprise, together with skills (abilities and processes), are the key competencies of the enterprise and are treated as resources [21]. Today's top priority in the management of both an enterprise and a scientific unit is competitiveness, increased to the rank of an ideology [22]. Competitiveness ceased to be a means and began to be an objective, where resources contribute to building this competitive advantage, especially in the age of globalisation. Such capabilities and resources are owned by e.g. the Building Research Institute, which, as a business entity on a basic level in market economy, is classified as a large enterprise due to the number of its employees.

An economy, region or entrepreneur whose activity does not provide the coherence of economic, social and environmental objectives cannot be competitive. This is demonstrated by e.g. M. Lubiński [23] in the definition of competitiveness within the principles of sustainable development. He claims that competitiveness is a valuing concept that determines a certain desired state that means multiple characteristics on a macro- and micro-economic scale, such as

- selling products with profit domestically and abroad,

- the ability to maintain and even increase market share,

- and the capacity for sustainable development over a long period.

Returning to the definition of entrepreneurship, according to the concept of J. B. Say, it should be noted that it plays not only an important role in the efficient allocation of existing resources, but also in the creation of new improved resources [24]. The search for and use of social and economic 
innovations, discovering new relationships in the existing economic system, recognising niches in the market, looking forward into the future and searching for and responding to changes are an integral part of entrepreneurship, which is an instrument for the success of not only an enterprise but scientific units as well.

The design of the development strategy for research institutes is based on information describing the state of the macro-environment of the organisation and of the competitive environment, together with the changes occurring in this area, as well as the situation inside the organisation - its resources and competencies. In relation to the macro-environment, one can distinguish a few areas: natural, socio-cultural, demographic, economic, legal and political, and technological environments [25]. A significant degree of predictability in the context of change characterises a number of factors that describe the natural, cultural and demographic environment, and also some economic variables and general technological trends. In these areas, one can observe factors whose changes are continuous in nature and exert a gradual effect on the market situation. In particular, careful monitoring and rapid response require variables from the legal and technological environments (e.g. disruptions).

A key element of the environment of a building research institute is the industry in which it operates and its specific nature. A commonly accepted model of competition in industry is the five forces model formulated by M.E. Porter [26], shown in Figure 2. Forces affecting the industry determine the profitability of the organisations operating within it. The higher the force, the lower the profitability. For example, the more accredited testing laboratories operating in a particular industry there are and the greater the bargaining power of buyers is, the lower the profitability of the services in this area will be. 


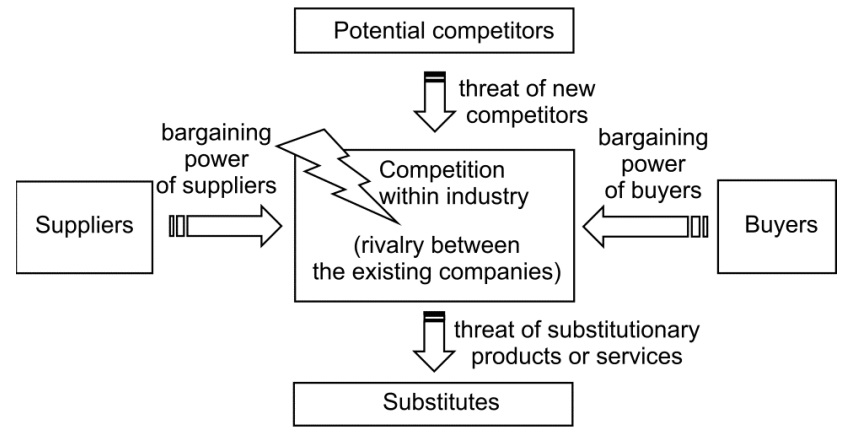

Fig. 2. Five forces model according to M. E. Porter

The history of the construction industry over the past 30 years has seen big changes in market mechanisms. National enterprises and scientific units at the beginning of the 1990s had little time to adjust to the new conditions of the market economy, hyperinflation and the access to budget funds for research. The late 1980s and the early 1990s were a time of crisis and transformation of the economy that impacted the further direction of the development of Polish scientific institutions. This period of adaptation to the new conditions of the market economy, and the response to the change by research institutes created the conditions for more effective connections between science and economy. Together with foreign capital, innovative technologies were transferred to Poland, in addition to the transfer of the scientific thought, results of research and development, patents and original ideas. These phenomena spurred a number of institutes in the construction industry to strengthen their approval and certification activities, followed by intensive development of the laboratory base and its digitisation. From the mid-90s, when the Building Research Institute (BRI) was entrusted with a leading role in the system of implementation of innovative construction products on the market, it operated in the industry within a market economy with virtually no competition. This situation may have had an influence on the non-optimal use of the research potential of the institute in favour of the engagement in service activities, and additionally, on the noticeable insufficient development of young scientific personnel resulting in a generational gap. On the European market, this situation began to change after 2004, and on the domestic market, at the end of the first decade of the 21st century. Therefore, the period between 2004 and 2014 should be considered a period when the scientific unit entered the area of the mechanisms of the market economy system, together with the mechanisms of increasing competition. These mechanisms 
intensify, especially as a result of legislative changes implemented in the system for the introduction of construction products onto the market.

In the light of the foregoing, and considering Porter's Five Forces Model, it must be noted that the forces acting on Polish scientific units are strengthening, resulting in their declining profitability. Therefore, against the backdrop of such market realities and ever increasing competition, a justified response from the institutes is, in determining their prospective directions of development, to strengthen their entrepreneurship activities, and not only ensuring balance and optimisation.

\subsection{KNOWLEDGE-BASED INNOVATION MODEL}

Innovation and entrepreneurship embedded in research and development for the purposes of practice, the primary activity of research institutes, is becoming a natural model for their operation. If we accept the view that innovation consists in the incorporation of knowledge in enterprises, there is no better application of this mechanism than in research institutes, which also partly exist as enterprises. The use of knowledge and intellectual capital for innovative purposes requires that the enterprise possesses a specific set of characteristics, the so-called innovative competencies, the possession of which is not the ultimate guarantor of launching a stream of innovation. A proinnovation model of the functioning of the enterprise or research institute is needed, which includes the shaping of the economic, social, cultural, legal and formal environments and management mechanisms.

In the knowledge-based innovation model [27], innovation originating from within the enterprise is a result of the interaction between three essential variables:

- the availability and quality of knowledge (both in the enterprise and the environment),

- other characteristics of the environment (the value system, the attitude to work, education level, the shape of legal standards governing the economic activity, the shape and stability of the structures of political power),

- the characteristics of the enterprise itself, referred to as innovative competencies.

The knowledge-based innovation model (Figure 3) presented by T. Borkowski and A. Marcinkowski distinguishes two main types of knowledge applied within an organisation:

- possessed by the employees - internal employee knowledge (wwp),

- accumulated in tangible media, such as books, instructions, user manuals, databases in the possession of the enterprise (libraries, computer centres, etc.) - internal material knowledge (wwm). 


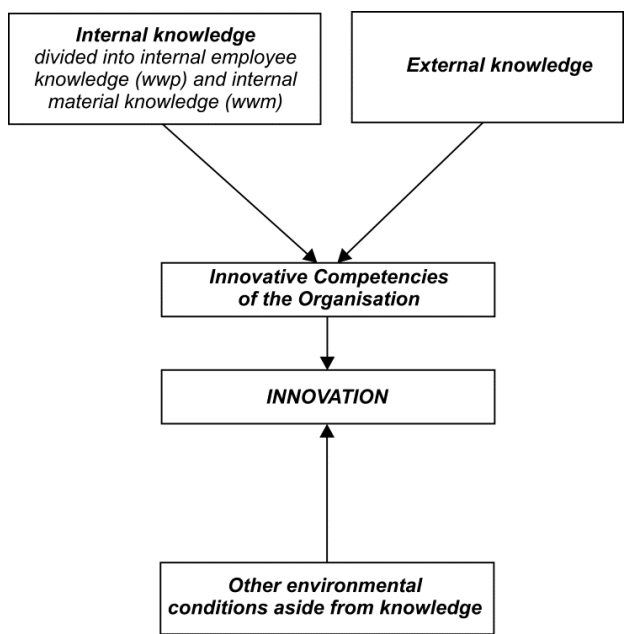

Fig. 3. Knowledge-based innovation model [27]

The employees' knowledge (wwp) is closely linked to material knowledge (wwm) - they are related to each other because, for employees to be able to effectively use material knowledge sources, they must be properly trained and possess some intellectual capital. Extensive resources in material knowledge (wwm) are a potentially strong incentive to train workers, and so contribute to the growth of the employee's knowledge (wwp). In the model being presented, external knowledge are those information resources that the organisation does not have, but at the same time this knowledge is located in its environment and can be absorbed under certain conditions. External knowledge is a powerful reservoir of information produced by the global society in the field of culture, politics and social, economic, technical and scientific issues, and many others.

Internal knowledge, together with intellectual capital, has a decisive impact on the innovative competencies of the organisation, which mean its intellectual ability to initiate, design, and implement innovation. This knowledge-based innovation model presented in the literature does not take into account sociological and psychological variables that, together with the phenomenon of a paradigm shift, are of essential significance. An important factor in the capacity of an enterprise to create innovation is also the organisational culture, often associated with values accepted and widely practised within the organisation. The components of these values and practices may or may not be conducive to innovation in a particular way. The role of the value system, combined with the 
development strategy, creates an enterprise culture oriented at innovation, that is strengthened by the management mechanism through the adoption of consistent policies.

\section{RESEARCH INSTITUTE AND ITS BUSINESS MODEL}

In the literature on the subject, there are many definitions and approaches to the concept of business model. In very simple terms, it is a business idea about how to generate profits - which in the case of an institute are associated with knowledge and finances. In the age of demanding quality and sales requirements, and a strong focus on increasing the operational efficiency (so-called costcutting), the business model can become an area of innovation to stay ahead of the competition in the area of strategy design. The determination of the business model allows for the proper adoption of the strategy for the development of the organisation. The strategy of the Building Research Institute has been structured in accordance with the diagram presented in Figure 4 - the strategy pyramid.

On the basis of an analysis and evaluation of the strategic potential, as well as the nature of its operation in the market conditions, it was found that the primary strength of a research institute is the knowledge and intellectual capital that form the foundation of the organisation's potential in building its competitiveness. Its source is the suitably high level of dynamics in the learning process and the transformation of knowledge into innovation, i.e. novelties that are associated with some actual market value, and their use in order to upgrade the internal structures [28] - organisational innovation.

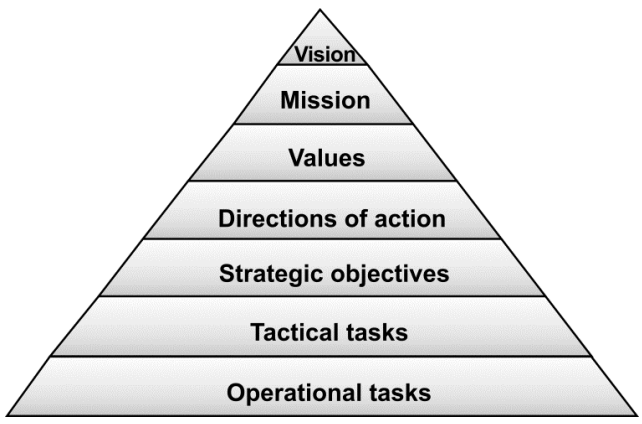

Fig. 4. Strategy pyramid 
Practically applied knowledge, data and information of the institute make it possible to solve problems and take appropriate market decisions. Knowledge is created and used in the mind of its holder. In a research institute, knowledge often translates not only into the quality of research and development, but also into the quality of the procedures, processes and organisational structures and culture of the unit [29]. Bearing the above in mind, the role of a building research institute is to achieve specialisation in the field of advanced knowledge - a specialisation model. The largest market, the market of abundance, the market of activities and profits, for a scientific unit is the market called "unresolved problems", where there are always many opportunities for those individuals that demonstrate leadership and prove their value by showing how to resolve these problems. In the case of the Building Research Institute, the business model adopted as the specialisation model is a response to the strategic potential that characterises this unit. BRI employs highly qualified specialists, researchers and experts from multiple disciplines of construction, with authority in the industry. In addition, the institute is an institutional expert, using its knowledge and experience based on the results of laboratory tests, including modern computing and simulation programmes.

Modern methods of engineering and research analysis go far beyond the machine equipment of testing laboratories. Global science and industry require more and more advanced analyses of complicated issues that exceed the research possibilities of even the advanced research centres. Increasingly, modern computation methods based on numerical analysis are being applied. This is a worldwide trend that is being enhanced by the growth and increasing accessibility of computing power. Computations are a simplification of the actual element. Theoretical and study works sometimes do not have sufficiently reliable checks of the effectiveness of functioning in real life conditions, which significantly impedes their practical application. Even widely recognised numerical methods are burdened with some error in the modelling and adoption of boundary conditions. This can impact the reliability of the calculations, and consequently the assessment of the product or structure.

As an example of an BRI scientific activity focusing on practical needs is the conduct of numerical computations using advanced methods in parallel to the laboratory and in-situ testing. The strength of a scientific research unit lies in the fact that the numerical computations can be compared with the results of product and building components testing. By comparing the results of the computations with the results of the tests [30,31,32], methods of modelling and adopting boundary conditions for numerical computations are further developed. This makes it possible to validate the computation methods and allows for the adoption of the correct conditions in computer simulations. 
Subsequently, one can use the already validated modelling methods in the assessment of products and facilities that are difficult or sometimes impossible to test under laboratory conditions or conditions of the actual operation of the structure.

Due to the constantly changing needs of the market, associated with large projects, such as underground structures, tower structures, heavy industrial buildings, large reservoirs and landfills, highways and large bridges, as well as in light of the rapid progress made in the last fifty years in the area of machinery and investment capabilities, the availability of materials and the development of computerisation and, above all, due to economic considerations, it is necessary to search for new construction and material solutions. However, the introduction of new products, materials or construction solutions for widespread use requires research that allows for an assessment of their behaviour in the conditions of an actual load. As a leader in the construction industry, BRI conducts a wide range of scientific research (within the framework of statutory works, internal research fund, and available external resources, e.g. from the National Science Centre (NCN), the National Centre for Research and Development (NCBR)). Multi-threaded research (laboratory, numerical and in-situ studies [33]) allows for the assessment of the behaviour of materials, design solutions with certain parameters and the development of recommendations for their reliable use in the conditions of their expected load, taking into account the influence of climatic conditions on both the strength and strain characteristics and durability of the materials used.

The above examples of BRI scientific research activities for purposes of practice and implementation, with a specific business model, make it possible to quickly develop and implement innovations, reduce activity costs, build a brand and be flexible in the network of long-term contacts. Appropriate management of knowledge and intellectual capital towards specialisation can be contrasted to working in an environment where competition cannot be achieved due to a lack of knowledge.

\section{MODEL OF A DEVELOPMENT MANAGEMENT SYSTEM}

The creation of the BRI development concept, in particular, takes into account the history of the formation of the organisational culture, including the formation of the environment and the internal structures. On the other hand, it was essential to find an answer to the question: what is required for a building research institute, such as BRI, to develop - as an organisation, as individual teams and as individual staff - and what spurs the development of the Institute in the scientific and expert fields? 
The BRI development concept is a proposal for a development management model aimed at increasing the effectiveness of programming and implementation of the development policy and raising the quality of the operation of the Institute. It provides an answer to the questions asked above.

\subsection{PROACTIVITY AND PARADIGM SHIFT}

Proactivity and paradigm are concepts that are an inherent part of a change, so an initiative was undertaken to use it for innovation. Proactivity is an attitude through which we assume that we decide about our lives by making choices. We hold the responsibility for what our lives will look like. The opposite attitude is a reactive approach, in which the outside world is responsible for the shape of our life and its conditions.

On the other hand, a paradigm is an accepted way of seeing reality in a certain field, doctrine, etc. The concept of paradigm was explained by the American physicist Thomas Samuel Kuhn in his book The Structure of Scientific Revolutions [34] first published in 1962. As a result of his research on the history of science, he presented the concept on the essence and development of science. A central role in this concept is the concept of the paradigm. Thomas Kuhn views the paradigm as widely recognised scientific achievements that provide the scientific community with model solutions in a certain period. The formation of a scientific community means that those who belong to it take a particular paradigm as a basis, a way of perceiving a particular reality, whose formula they unanimously adopt and they are faithful to this particular research tradition. Such a research tradition is called normal science by Kuhn.

The specification of paradigm allows scholars to conduct specialised research, design increasingly more precise equipment and use it in a consistent manner. It also makes it possible to collect facts and build theories, that is perform activities that focus primarily on providing balance and optimisation. It is this perception of reality that Joseph Schumpeter referred to as the opposite of the dynamic imbalance, that is the standard of a healthy economy that introduces the effectiveness of activities performed by an innovative entrepreneur - innovations.

The mechanisms of balance and optimisation, being closely oriented around adopted rules, suppress innovation that could call into question the fundamental assumptions of the accepted paradigm. The scholars that formulate a different theory than the widely accepted paradigm usually encounter intolerance in their community. For Claudius Ptolemy, for example, the Earth was the centre of the universe - an accepted paradigm. Everything was reinterpreted differently, though, when Nicolaus Copernicus changed the paradigm by putting the Sun in the centre, which caused many objections 
and persecution. According to Kuhn's theory, each significant achievement in the field of science must first break the traditional way of thinking and the outdated paradigms. The same applies to other fields of human activity, including the development of various units or organisations.

When designing a strategy for the development of a building research institute, one must often change the management paradigm of that unit in order to reach a new level of development of this organisation.

\subsection{MODEL ASSUMPTIONS}

The institute development concept incorporates a few assumptions relating to the BRI activities:

- enhance the proactivity of the Institute in the works performed to ensure the technical and functional quality of civil structures,

- focus research and development on practice-oriented implementations, not only as a response to the technical problems of the construction market, but as a method of preventing them from occurring in the first place,

- the cooperation at all levels of institute activity, both within the organisational structure and with market participants, should be based on principles of synergy and a win-win approach,

- research and development should be the fruit of ongoing cooperation within the construction market and co-financed by the market,

- scientific and professional development should be based on a system of management of knowledge and intellectual capital.

The creation of the development concept requires learning about the organisation, its macro- and micro-environment, the mechanisms of operation, origins and cause-and-effect relationships. Getting to know the history of the organisation is essential for designing its future - the vision of the Building Research Institute - the horizon towards which one must be heading for the Institute to be a leader in the creation of the development of the construction industry, which serves as a support for the practice. The BRI development concept is first and foremost a systemic mechanism - a development management system model.

\subsection{Presentation of the MOdel}

The future of the BRI is the scientific and expert development of its employees, the effects of which should be reflected not only in setting the direction of the development of construction in the country, Europe and worldwide, but, first and foremost, in reliable, high-quality performance of the 
research and development works, expert reports and other works related to the statutory activity of the Institute.

The BRI mission is to create high quality and innovativeness in construction by:

- ensuring the development of its employees,

- conducting scientific, research and expert works,

- responding to the needs of market participants.

The BRI development management system model, as a kind of driving force, means creating habits of high effectiveness which lead to the achievement of the BRI strategic objectives. The development concept uses the highly effective habits formulated by Stephen R. Covey [35], which assume an improvement in effectiveness by changing specific habits. The organisation learns the mechanisms that affect the development.

According to the accepted theory, the first three habits - be proactive, begin with the end in mind and put the most important things first - are the basis for internal development. The next three habits are related to the development of external cooperation: in communication - seek first to understand, then to be understood, and then also the principles: think win-win and synergise (working in a team). The seventh habit, called sharpening the saw, is the continuous improvement of these habits. Such a development management system model, implemented at all organisational levels, makes it possible to unify the principles that lead to the development of employees and thus the institute by introducing, first and foremost, the habit of being proactive.

The driving force of the adopted model lies within the structure of the management mechanisms contained within four main areas: decision-making authorisations (decisions and standards), types of motivation (motivation and obligations), information flow (information and mind-set) and organisational structure (structure and connections). These mechanisms are supported by activities relating to scientific development (people and teams), the growth of finance for science, the consolidation of scientific and expertise potential, the expansion into international markets, diversification of the core business activity and the implementation of changes in the strategic financial management of the unit.

The whole model is supported on two pillars - scientific development and expertise development in cooperation with the entrepreneur - making up the environment of the innovation. 


\section{STRATEGY AS AN ACTIVITY PROGRAMME}

In the context of business, strategy is, first and foremost, supposed to allow the use of many different methods to build an organisation that acts faster, more efficiently and effectively than its competitors. Among many definitions, it is important to be able to achieve tangible results for the Institute in practice through various strategic concepts.

The results of analysis of strategic potential justify claims that BRI is functioning in an attractive market in a relatively stable environment and has a considerable competitive advantage that it is able to maintain due to its great financial strength. This means that the institute is in a convenient position in the market to draw benefits from its strengths, to use the development opportunities in the environment and counteract emerging threats. This analysis leads to one of the four strategic situations highlighted by H. Weihrich, i.e. to "maxi-maxi" strategy [36], which is making use of the strengths of the units and the chances emerging in its environment. It is a strategy of strong expansion, entering new markets, investment and further building the competitive advantage. The recommended actions include proactive market penetration and development, the development of services and products, vertical or horizontal integration, as well as various forms of diversification — making its offer more diverse in order to reduce the risk to the business.

When implementing a new approach to the management of the research institute, the first stage included the analysis and evaluation of the strategic potential of the general relationships with the environment, research and development, the services for the needs of the construction market, the strategy of development, distribution, promotion and advertising, pricing, HR management, materials management and fixed assets as well as financial strategy. In the subsequent stages, the Institute development strategy was prepared in the form of the BRI Activity Programme for 20152018. The mid-level management determined the BRI vision, mission and values, and established lines of action, strategic objectives and tactical and operational tasks. The strategic objectives were assigned to individuals responsible for their fulfilment and then described within 14 strategic projects, including the determination of their time frames (tools such as the Gantt chart), necessary resources, indicators and risk that form a coherent whole. The BRI Steering Committee for Scientific Development and Post-doctoral Colloquium were set up as tools to support innovation in the Institute.

Due to its principles, the introduced management model strengthens strategic thinking that is no longer based on the "road map" (generic) model but on the "compass", where the mission of the organisation becomes the constitution for its employees [37]. In management, the power of focus on 
principles is built on the unity in the organisation whose primary need includes communication and understanding. Thus, work ethics are based on the engagement in appropriate, jointly adopted objectives, and the power of focus on the principles inspires a desire to take risks for the purposes of innovation and entrepreneurship. Development occurs.

\section{SUMMARY}

The model of a development management system implemented for the strategy deployed for the Building Research Institute can be defined in terms of building research innovation, the method of achieving progress, and shaping the research area as an element in the engineering of construction projects. The essence of the presented issue, and at the same time a research challenge, is to define the tasks and methods of action for building research institutes working for the construction industry.

The concept of the model is an original solution created by the author, and can be assumed as a proposal for an innovative mechanism used to increase the effectiveness of the programming and implementation of the development policy, and improve the quality of functioning of a building research institute. The development management system included in this model is a set of actions targeting at the effective use of human and tangible resources, undertaken in a coordinated manner and leading to the achievement of previously established objectives. The market activity of building research institutes is directly or indirectly involved in construction projects, which translates into market mechanisms, such as innovation and competitiveness. In addition, it indicates the participation of a building research institute in the engineering of construction projects as a key to entrepreneurship and implementations. 


\section{REFERENCES}

1. Act of 30 April 2010 on research institutes (Dz. U. of 2010, No 96, item 618, as amended), [in Polish].

2. L. Czarnecki, D. Van Gemert, "Scientific Basis and Rules of Thumb in Civil Engineering: Conflict or Harmony? It is better to be roughly right than precisely wrong, J. M. Keyness, 1924", Bull. Pol. Ac.: Tech. 64 (4), in printing.

3. L. Czarnecki, M. Kaproń, "Directions of research and development in construction", Wiadomości Projektanta Budownictwa 6: 30-33, 2010 [in Polish].

4. L. Czarnecki, M. Kaproń, "Sustainable construction as a research area", International Journal of the Society of Materials Engineering for Resources 17: 99-106, 2010.

5. W. Radomski, "Science in the Civil Engineering in comparison with the Building Research Institute's role", The Building Research Institutes' Strategy, BRI Publishing, Warsaw, pp. 17-38, 2015 [in Polish].

6. A.M. Brandt, W. Radomski, "Science in Contemporary Civil Engineering", Inżynieria i budownictwo LXX, 4: 187-195, 2014.

7. J. Schumpeter, "Business Cycles: A Theoretical, Historical and Statistical Analysis of the Capitalist Process", Philadelphia, p. 84, USA, 1982.

8. The contribution of building research institutes in Polish science achievements versus the institues's representatives delegation in advisory bodies of the Ministry of Science and Higher Eductaion (raport for the Main Council of the Research Institutes), IC Raport, p. 20, 2014 [in Polish].

9. Collective work edited by L. Czarnecki, "Building research institutes' strategy", BRI Publishing, Warsaw, 2015 [in Polish].

10. Collective work edited by O. Kapliński, "Methods and models of research in construction projects", PAN KILiW IPPT Institute of Fundamental Technological Research of Polish Academy of Sciences, Warsaw, 2007 [in Polish].

11. O. Kapliński, "Methods and Models of research in construction projects", PAN KILiW IPPT Institute of Fundamental Technological Research of Polish Academy of Sciences, Warsaw, 1997 [in Polish].

12. O. Kapliński, "Modelling of construction processes: A managerial approach", PAN KILiW IPPT Institute of Fundamental Technological Research of Polish Academy of Sciences, Warsaw, 1997 [in Polish].

13. O. Kapliński, E.K. Zavadskas, "An overview of the problems related to research in construction engineering, management and economics in Poland", Journal of Civil Engineering and Management 8 (4): 231-239, 2002.

14. S. Gomułka, "The theory of innovation and economic growth", Center for Social and Economic Research CASE, Warsaw, pp. 17-43, 1998 [in Polish].

15. J. Schumpeter, "The Theory of Economic Development", Harvard University Press, Cambidge, Massachusetts, 1934. Polish edition by PWN, Warsaw, p. 128, 1960.

16. A. Nowak-Far, "Global competition. Startegic management of innovations in multinational companies", Polish Scientific Publishers PWN, Warsaw-Poznań, p. 29, 2000.

17. Collective work, scientific editing by E. Okoń-Horodyńska, "The role of the Polish science in increase of the innovative economy", Polish Economic Society Publisher, Warsaw, 2004 [in Polish].

18. P. F. Drucker, "Inspiration and luck mean innovation and entrepreneurship", EMKA Studio, Warsaw, pp. 2129, 2004 [in Polish].

19. Effects of research institutes activity, Supreme Audit Office, KNO-4101-009-00/2014 Nr ewid. 37/2015/P/14/070/KNO, Warsaw, 2015, pp. 9-14 [in Polish].

20. L. Clarke, "Management of change", Gebethner i S-ka, Warsaw, p.9, 1997 [in Polish].

21. M. Bartnicki, "The company's competence”, Placet Publishing Agency, p. 48, 2002 [in Polish].

22. B. Wawrzyniak, "Restoration of the company to meet the $21^{\text {st }}$ century", Poltex, Warsaw, pp. 36, 56-57, 1999 [in Polish].

23. M. Lubiński, „Competitiveness of the economy. Concepts and method of measuring”, International competitiveness of the economy - conditions and prospects. Reports on competitiveness , IRiSS, Warsaw, pp. 10-11, 1995 [in Polish].

24. Collective work edited by E. Skawińska, "The competitiveness of companies - a new approach", Polish Scientific Publishers PWN, Warsaw-Poznań, p. 85, 2002 [in Polish].

25. K. Obłój, "Organization strategy”, II edition. National Economic Publishing, Warsaw, 2007 [in Polish].

26. M. E. Porter, "Competitive strategy. Analyses methods of sectors and competitors", National Economic Publishing, Warsaw, 1997 [in Polish].

27. T. Borkowski, A. Marcinkowski, "Socio-psychological conditions of introduction innovations into the enterprise", The role of Polish science in the growth of economic innovation, Polish Economic Society Publishing, Warszawa, pp. 197-219, 2004 [in Polish].

28. L. Panasiewicz: "The hidden advantage - organizational culture as a factor in the success of modern enterprises”, Lublin University of Technology, Lublin, 2013 [in Polish]. 
29. M. Nikilewicz-Pijaczyńska, M. Wachowska, „Knowledge - Human Capital - Innovations”, Digital Library of University of Wroclaw, University of Wroclaw, Wroclaw, 2012 [in Polish].

30. A. Piekarczuk, M. Malesa, M. Kujawinska and K. Malowany, "Application of hybrid FEM-DIC method for assessment of low cost building structures" Experimental Mechanics 52: 1297. doi:10.1007/s11340-012-96162. (2012)

31. A. Piekarczuk, K. Malowany, "Comparative analysis of numerical models of arch-shaped steel sheet sections". Archives of Civil and Mechanical Engineering: 16 (4): 645-658. DOI:10.1016/j.acme.2016.04.006, 2016.

32. M. Kozłowski, M. Kadela, A. Kukiełka, "Fracture Energy of Foamed Concrete Based on Three-Point Bending Test on Notched Beams", $7^{\text {th }}$ Scientific-Technical Conference on Material Problems in Civil Engineering MATBUD'2015, Procedia Engineering 108: 349-354, DOI:10.1016/j.proeng.2015.06.157, 2015.

33. M. Kadela, M. Kozłowski, "Foamed Concrete Layer as Sub-Structure of Industrial Concrete Floor", World Multidisciplinary Civil Engineering-Architecture-Urban Planning Symposium 2016, WMCAUS 2016 [to be published in Procedia Engineering] 2016.

34. T.S. Kuhn, "The Structure of Scientific Revolutions", the University of Chicago Press, 1962.

35. S.R. Covey, "7 habits of effective action", Rebis Publishing House, Warsaw, 2006 [in Polish].

36. H. Koontz, H. Weihrich, "Essential of Management”, McGraw - Hill, New York, p. 94, 1990.

37. S.R. Covey, "Principles of effective leadership", Rebis Publishing House, Warsaw, p. 109, 2014 [in Polish].

Received 21.10.2016

Revised 13.12.2016

\section{LIST OF FIGURES AND TABLES:}

Fig. 1 The basic relationship between technological and organizational innovations [16]

Rys. 1 Podstawowe zależności pomiędzy innowacjami technologicznymi i organizacyjnymi [16]

Fig. 2 Five forces model according to M. E. Porter

Rys. 2 Model pięciu sił wg M.E. Portera

Fig. 3 Knowledge-based innovation model [27]

Rys. 3 Model innowacji opartej na wiedzy [27]

Fig. 4 Strategy pyramid

Rys. 4 Piramida strategii 


\section{STRATEGIA INSTYTUTÓW BADAWCZYCH W BUDOWNICTWIE W KSZTALTOWANIU PRZESTRZENI BADAWCZEJ}

Slowa kluczowe: instytut badawczy, innowacja, konkurencyjność, strategia rozwoju, metody budowlane, projekty inżynierii budowlanej

\section{STRESZCZENIE:}

Najbardziej radykalne i przekształcające gospodarkę w konkurencyjną są te innowacje, które pozwalają ludziom uwolnić swoją kreatywność - realizować swoje marzenia. Stworzenie społeczności w instytucie badawczym, w którym pracownicy z przedsiębiorcami tworzą jeden zespół pracujący na potrzeby budowania przewagi konkurencyjnej, to główny cel stawiany jednostkom naukowym w dobie innowacyjnej gospodarki. Największym rynkiem działań dla jednostki naukowej jest rynek zwany „,nierozwiązane problemy”, gdzie zawsze istnieje wiele możliwości dla tych jednostek, które wykazują się inicjatywą i dowodzą swojej wartości, pokazując, jak rozwiązać owe problemy. W kształtowaniu przestrzeni badawczej bardzo ważne jest stworzenie odpowiedniego otoczenia rynkowego sprzyjającego przenoszeniu wiedzy z instytucji naukowych do przedsiębiorstw, jednocześnie wzmacniając strategię jednostek naukowych skierowaną na zarządzanie przez zasady w oparciu o model systemu zarządzania rozwojem. Prezentowana w artykule koncepcja owego modelu jest rozwiązaniem autorskim i można ją przyjąć, jako propozycję mechanizmu innowacyjnego mającego na celu zwiększenie skuteczności programowania i wdrażania polityki rozwoju oraz podniesienie jakości funkcjonowania instytutu badawczego budownictwa. System zarządzania rozwojem jest ujęty w prezentowanym modelu jako zespół działań zmierzających do efektywnego wykorzystania zasobów ludzkich i środków materialnych, podejmowanych w skoordynowany sposób, prowadzących do osiągnięcia wcześniej założonych celów. Działalność rynkowa instytutów badawczych budownictwa ma pośredni lub bezpośredni udział w przedsięwzięciach budowlanych, co daje umocowanie w mechanizmach rynkowych jak innowacje i konkurencyjność. Ponadto wskazuje udział instytutu badawczego budownictwa w inżynierii przedsięwzięć budowlanych, jako klucz w drodze do przedsiębiorczości i wdrożeń.

W dyscyplinie naukowej budownictwo, nauka i inżynieria przenikają się: powstającym dzietom inżynierskim o wielkich gabarytach, decydujących o bezpieczeństwie setek użytkowników i projektowanej trwałości liczqcej dziesiątki lat musi towarzyszyć przeświadczenie, że sa oparte na podstawach naukowych [2]. Badania naukowe i prace rozwojowe w dyscyplinie naukowej budownictwo (w dalszym tekście używać będziemy terminu budownictwo) powinny zawierać się w ramach E3 (Energia x Ekologia x Ekonomia), tzn. w granicach wyznaczonych przez minimum zużycia energii, minimum oddziaływania na środowisko i racjonalizacji ekonomicznej [3], czyli muszą odpowiadać wymaganiom zrównoważonego rozwoju [4]. Budownictwo należy do najstarszych dziedzin techniki i korzysta z wielu nauk podstawowych, technicznych i społecznych, dlatego badania prowadzone są w wielu instytucjach naukowych. Budownictwo, jako dyscyplina naukowa, może rozwijać się efektywnie przede wszystkim dzięki stałej więzi nauki z praktyką przy inwestycjach realizowanych na dużą skalę, gdzie często praktyka wyprzedzała i wyprzedza teorię [5].

Prezentowane w niniejszym artykule podejście strategiczne włącznie z przyjętymi kierunkami działań wpisuje się w strategię europejskich instytutów badawczych budownictwa zrzeszonych w European Network of Building Research Institutes (ENBRI) [9]. Instytuty badawcze budownictwa odgrywają bardzo istotną rolę w przedsięwzięciach budowlanych zarówno na etapie innowacji i wdrożeń, jak i roli eksperta, rzeczoznawcy 
budowlanego bezpośrednio w przedsięwzięciu budowlanym. W przedsięwzięciu budowlanym [10] mieszczą się takie działania jak: przygotowanie koncepcyjne, organizacja i realizacja budowy, montaż, remont i rozbiórka, a także koordynacja, monitoring procesów kierowania, różne rodzaje procesów budowlanych. Dlatego wiedza i kapitał intelektualny jednostki naukowej znajduje swój szczególny udział wśród powyższych działań. Instytut badawczy budownictwa jest nie tylko rzeczoznawcą instytucjonalnym biorącym udział bezpośrednio w przedsięwzięciach budowlanych, ale też, a raczej przede wszystkim jednostką naukową, która w sposób pośredni poprzez prowadzenie badań naukowych i prac rozwojowych dla potrzeb praktyki uczestniczy w przedsięwzięciach budowlanych od programowania, planowania po rozbiórkę i recykling materiałów.

W kontekście oceny działalności instytutu badawczego, zastanawiającym jest fakt dostrzeżenia nawet w dobrze działającym instytucie potrzeby zmian i to w zakresie globalnym jego funkcjonowania. Jest to innowacja sama w sobie, w kontekście przedsięwzięć instytutu, mechanizmów zarządczych dotyczących decyzji i norm, motywacji, przepływu informacji, sposobu myślenia, czy struktury organizacyjnej. Wszystkie te działania ściśle powiązane są z modelem systemu zarządzania rozwojem instytutu badawczego i ukierunkowane na rozwój potencjału związanego z działalności wdrożeniową. Przedsiębiorcy i jednostki naukowe powinny postrzegać zmianę jako coś normalnego i zdrowego, z zaznaczeniem, że należy nią zarządzać łącząc naukę z biznesem.

W modelu innowacji opartej na wiedzy [24] innowacja rodząca się w przedsiębiorstwie jest efektem interakcji między trzema zasadniczymi zmiennymi:

- dostępnością i jakością wiedzy (w przedsiębiorstwie i otoczeniu),

- $\quad$ innymi cechami otoczenia (systemem wartości, postawą wobec pracy, poziomem wykształcenia, kształtem norm prawnych regulujących działalność gospodarczą, kształtem i stabilnością struktur władzy politycznej),

- $\quad$ cechami samego przedsiębiorstwa, określonymi mianem kompetencji innowacyjnych.

Wykorzystana w praktyce wiedza instytutu, dane i informacje, pozwalają na rozwiązywanie problemów lub podjęcie właściwych decyzji rynkowych. Wiedza powstaje i jest wykorzystywana w umyśle jej posiadacza. W instytucie badawczym wiedza często przekłada się nie tylko w jakość badań naukowych i prac rozwojowych, lecz także na jakość procedur, procesów i struktur organizacyjnych oraz kulturę jednostki [26]. Mając na uwadze powyższe - rolą instytutu badawczego budownictwa jest osiągnięcie wysokiej specjalizacji w dziedzinie zaawansowanej wiedzy - model specjalizacji. Największym rynkiem, rynkiem dostatku, rynkiem działań i zysku dla instytutu badawczego jest rynek zwany „nierozwiązane problemy”, gdzie zawsze istnieje wiele możliwości dla tych jednostek naukowych, które wykazują się inicjatywą i dowodzą swojej wartości, pokazując, jak rozwiązać owe problemy.

Koncepcja modelu jest rozwiązaniem autorskim i można ją przyjąć jako propozycję mechanizmu innowacyjnego mającego na celu zwiększenie skuteczności programowania i wdrażania polityki rozwoju oraz podniesienie jakości funkcjonowania jednostki naukowej. System zarządzania rozwojem jest ujęty w prezentowanym modelu jako zespół działań zmierzających do efektywnego wykorzystania zasobów ludzkich i środków materialnych, podejmowanych w skoordynowany sposób, prowadzących do osiągnięcia wcześniej założonych celów. 
